\title{
HUBUNGAN KONFORMITAS DAN KECERDASAN EMOSIONAL TERHADAP AGRESIVITAS PADA REMAJA MADYA DI SMAN 7 DENPASAR
}

\author{
Anak Agung Ayu Nisha Amanda, David Hizkia Tobing \\ Program Studi Psikologi, Fakultas Kedokteran, Universitas Udayana \\ nishaamanda@rocketmail.com
}

\begin{abstract}
Abstrak
Pengaruh normatif dan pengaruh informasi berdampak pada tingkah laku seseorang yang disebut dengan konformitas. Konformitas bisa berdampak negatif dan positif, konformitas negatif contohnya adalah tawuran yang dapat merujuk ke tindak agresivitas. Remaja yang memiliki rentang usia 13-18 rentan terhadap tindak agresivitas terkait dengan emosi remaja yang fluktuatif (Rice, 2001). Agresivitas yang tinggi dapat diturunkan dengan kecerdasan emosional yang tinggi, karena dengan memiliki kecerdasan emosional yang tinggi seseorang mampu mengenali emosi diri dan orang lain dan mampu mengelola emosi diri. Penelitian ini bertujuan untuk mengetahui adanya hubungan konformitas dan kecerdasan emosional terhadap agresivitas pada remaja madya di SMAN 7 Denpasar.

Subjek dalam penelitian ini adalah 226 orang siswa kelas I dan II SMAN 7 Denpasar berusia antara 1518. Instrumen penelitian ini adalah skala agresivitas $(\alpha=0.882)$ Buss dan Perry (dalam Bryant \& Smith, 2001), skala konformitas $(\alpha=0.902)$, dan skala kecerdasan emosional $(\alpha=0,872)$ (Simarmata, 2005).

Hasil analisis regresi berganda menghasilkan $\mathrm{R}=0,452(\mathrm{~F}=28,667 ; \mathrm{p}<0,05)$ dapat dikatakan bahwa konformitas dan kecerdasan emosional memiliki hubungan terhadap agresivitas. Hasil korelasi parsial antara konformitas dengan agresivitas dengan mengontrol variabel kecerdasan emosional adalah 0,300 $(\mathrm{p}<0,05)$ yang berarti konformitas dengan agresivitas memiliki hubungan yang positif yang artinya adalah semakin tinggi konformitas, semakin tinggi pula tingkat agresivitas. Hasil korelasi parsial antara kecerdasan emosional dengan agresivitas dengan mengontrol variabel konformitas adalah $-0,256(p<0,05)$ yang berarti kecerdasan emosional dengan agresivitas memiliki hubungan yang negatif yang artinya semakin tinggi kecerdasan emosional seseorang, maka tingkat agresivitasnya semakin rendah.
\end{abstract}

Kata Kunci : Agresivitas, Konformitas, Kecerdasan Emosional, Remaja Madya

\begin{abstract}
Normative influence and informational influence has an impact to people's behavior that called conformity. Conformity has positive and negative impact towards people, the example of negative conformity is gang fight and could reconcile as aggressive behavior. Teenagers within the age between 13-18 years old are easily tent to do aggressive behavior that cause by the emotion of the teenagers are fluctuating (Rice, 2001). High level of aggresion could reduce by having a high level of emotional inteligence, by having a high level of emotional intelligence someone could recognize their own emotion and others and could organize their emotion. The aimed of this research is to find out the relationship between conformity and emotional intelligence towards aggression of middle adolescence at SMAN 7 Denpasar.

Subjects in this study were 226 from first and second grade at 7 public high school students in Denpasar which consist between the age 15-18 years old. The instrument of this research are aggression scale $(\alpha=$ 0.882 ) by Buss and Perry ( in Bryant $\&$ Smith, 2001), conformity scale with the value $\alpha=0.902$, and emotional intelligence scale $\mathrm{w}(\alpha=0,802)$ (Simarmata, 2005).

The result of multiple regression analysis shows $\mathrm{R}=0,452(\mathrm{~F}=28,667 ; \mathrm{p}<0,05)$ it can be stated that there is a relationship between conformity and emotional intelligence towards aggression. The result of partial correlation analysis shows correlation coefficient conformity and aggression with controlling the emotional intelligence is $0,300(\mathrm{p}<0,05)$ and so conformity and emotional intelligence have a positive correlation, which means the higher level of conformity could increase the level of aggression. While the result of partial correlation analysis shows correlation coefficient between emotional intelligence and aggressive with controlling conformity is $-0,256(\mathrm{p}<0,05)$ and so the emotional intelligence and aggressive have a negative correlation which means the higher level of emotional intelligence could reduce the level of aggression.
\end{abstract}

Keywords: Aggression, Conformity, Emotional intelligence, Middle Adolescence 


\section{LATAR BELAKANG}

Masa remaja identik dengan masa pubertas, di masa ini terjadi perubahan fisik di semua bagian tubuh baik ekternal maupun internal yang juga mempengaruhi psikologis remaja (Hurlock, 2003). Di dalam masa remaja juga terdapat tahapan perkembangan yang salah satunya adalah tahapan psikososial yang menurut Erikson (dalam Myers, 2014) didefinisikan sebagai masa pencarian identitas sebagai konsepsi koheren diri yang terdiri dari tujuan, nilai, dan keyakinan yang dipercayai sepenuhnya oleh orang yang bersangkutan. Pada masa ini, remaja lebih banyak menghabiskan waktu bersama dengan teman sebaya dibandingkan dengan keluarga, oleh karena itu remaja menganggap teman sebaya sebagai tokoh panutan, teman, dan kedekatan yang mana hal ini didukung oleh pernyataan dari Czikzentmihalyi (dalam Prawira, 2014).

Teman sebaya merupakan tempat untuk membina hubungan dekat yang berfungsi sebagai tempat berlatih untuk hubungan yang akan dibina pada saat dewasa (Buhrmester, 1996). Masa remaja dibagib menjadi 3 bagian yaitu masa remaja awal, remaja madya, dan remaja akhir (Gunarsa \& Gunarsa, 2012). Masa remaja awal dan remaja madya merupakan masa yang paling kuat untuk mendapat pengaruh dari teman sebaya dan akan menurun pada masa remaja pertengahan seiring dengan mendekatnya kembali hubungan remaja dengan orangtua (Myers, 2014).

Remaja madya merupakan remaja yang memiliki rentang umur dari 13-18 tahun (Gunarsa \& Gunarsa, 2012). Pada usia 13-18 dikatakan sebagai usia yang rentan terhadap tindak agresivitas terkait dengan emosi remaja yang sedang fluktuatif. Remaja di dalam tahapan perkembangan psikososial akan banyak melakukan interaksi dengan individu, masyarakat maupun organisasi lain, oleh karena itu remaja akan mendapat pengaruh dari individu maupun masyarakat yang diajak melakukan interaksi. Pengaruh tersebut dapat berdampak ke tingkah laku yang disebut dengan konformitas (Yuliana, 2013).

Konformitas akan terjadi apabila seseorang melakukan interaksi dengan orang lain dan menampilkan perilaku karena orang lain menampilkan perilaku tersebut (Sears, 2002). Adapun alasan mengapa seseorang melakukan konformitas adalah keinginan agar diterima secara sosial atau yang disebut dengan pengaruh normatif. Pengaruh normatif akan terjadi ketika kita mengubah perilaku kita untuk menyesuaikan diri dengan norma kelompok atau standar kelompok agar kita diterima secara sosial, selain itu adanya pengaruh informasi juga mendorong seseorang untuk melakukan konformitas terkait dengan tendensi seseorang untuk menyesuaikan diri agar diterima oleh lingkungan sekitar (Taylor, Peplau,\& Sears, 2009).

Pengaruh normatif dapat memberikan dampak positif maupun negatif, seperti individu yang mampu mengikuti aturan-aturan yang berlaku di masyarakat dengan baik, namun di sisi lain individu juga dapat terpengaruh dengan lingkungan sosial untuk melakukan perilaku yang negatif yang terkait dengan konformitas yaitu tawuran (Yuliana, 2013). Peneliti memutuskan untuk memfokuskan penelitian di salah satu SMA Negeri di Denpasar dengan alasan jumlah murid yang lebih banyak dan kasus-kasus kekerasan yang lebih banyak terjadi di SMA Negeri di Denpasar. Peneliti melakukan wawancara dengan salah satu guru di SMA Negeri Denpasar mengenai remaja, beliau mengatakan bahwa banyak hal-hal yang dapat terjadi pada masa remaja seperti yang akhir-akhir ini digemari oleh remaja yaitu internet, remaja sekarang menggunakan internet khususnya media sosial untuk mencurahkan isi hati dan emosi.

Berdasarkan hasil studi pendahuluan yang dilakukan peneliti di SMAN 7 Denpasar melalui wawancara dengan beberapa murid, peneliti mendapatkan beberapa fakta yang terkait dengan penelitian yaitu bahwa di luar organisasi yang dibentuk oleh pihak sekolah, murid-murid membentuk organisasi lain atau yang biasa disebut dengan geng. Muridmurid membentuk geng berdasarkan tahun angkatan pada awal bersekolah di SMAN 7 Denpasar. Menurut sumber yang telah diwawancara, pertengkaran antar geng terjadi pada saat semua murid sedang berkumpul di lapangan sekolah. Salah satunya adalah pada saat ulang tahun sekolah geng dari angkatan 23 dan 24 bertengkar hanya karena saling ejek ketika berlangsungnya lomba untuk memperingati ulang tahun sekolah. Pertengkaran terjadi karena diawali oleh aksi saling ejek antar geng, namun pertengkaran tersebut hanya sebatas adu mulut karena pihak sekolah segera melerai pertengkaran tersebut. Fakta lain yang ditemukan oleh peneliti adalah kebiasaan bolos siswa, salah satu murid mengatakan bahwa setiap harinya ada saja yang beberapa siswa yang bolos. Para murid yang bolos sekolah akan pergi dari sekolah sendirisendiri dan akan mencari tempat untuk berkumpul bersama.

Remaja banyak melakukan interaksi dengan teman sebaya di sekolah. Teman sebaya dianggap memengaruhi perkembangan kepribadian seseorang. Apabila individu tidak memiliki kontrol terhadap dirinya dan tidak mampu memilahmilah perbuatan mana yang harus ditiru, remaja tersebut akan mudah mengimitasi perilaku-perilaku buruk yang ada (Yusuf, 2011). Perilaku buruk tersebut seperti melanggar peraturan sekolah dan merujuk pada kekerasan.

Kekerasan adalah suatu hal yang tidak jarang lagi kita temui. Beberapa media pun banyak memaparkan kasus agresivitas terutama pada remaja seperti media massa, media elektronik sampai media cetak. Bentuk-bentuk dari kekerasan yang dilakukan remaja sangatlah beragam, hal ini dapat dilihat dari meningkatnya kasus kekerasan yang dilakukan oleh remaja secara individual maupun kelompok (Taylor, Peplau, \& Sears, 2009). Agresivitas yang semakin meningkat di kalangan remaja pasti akan meresahkan lingkungan sekitar 
seperti di lingkungan keluarga, sekolah dan masyarakat. Hal tersebut terjadi karena sesama individu pasti akan berinteraksi satu sama lain. Tidak semua interaksi yang dilakukan bersifat positif, melainkan ada juga yang negatif seperti perkelahian, tawuran yang pada akhirnya akan merujuk ke agresivitas.

Tindak agresivitas yang dilakukan oleh remaja berkaitan dengan emosi remaja yang dapat dikatakan fluktuatif (naik-turun) berkaitan dengan hormon dan meningkatnya emosi-emosi negatif, oleh karena itu pada masa-masa inilah remaja sulit mengontrol emosinya (Hurlock, 2003). Faktor lain yang menjadi penyebab dari pergolakan emosi yang dialami oleh remaja, yaitu lingkungan sosial, lingkungan keluarga, sekolah, dan masyarakat (Dewi, 2012). Remaja yang melakukan tindak agresivitas dikarenakan remaja yang tidak mampu mengelola emosi diri dengan baik, sehingga ketika emosi memuncak dan tidak mampu dibendung lagi, emosi tersebut akan meluap-luap dan remaja akan melakukan tindakan yang tidak akan disadari seperti tindak agresivitas (Kurnia, Hardjajani, \& Nugroho, 2012).

Berdasarkan penelitian yang dilakukan oleh Dewi (2012) dikatakan bahwa terdapat hubungan yang signifikan diantara kecerdasan emosional dengan agresivitas. Remaja yang memiliki kecerdasan emosional yang tinggi cenderung mampu untuk mengelola emosi dan mengenali perasaan dengan baik. Hal tersebut sesuai dengan hasil penelitian yang dikemukakan oleh Kurnia, Hardjajani, \& Nugroho (2012) bahwa adanya hubungan negatif antara kecerdasan emosi dengan agresivitas pada remaja awal yang dapat dikatakan bahwa semakin tinggi kecerdasan emosi, semakin rendah agresivitasnya dan sebaliknya semakin rendah kecerdasan emosi, semakin tinggi agresivitas.

Kecerdasan emosional adalah kemampuan untuk memotivasi diri sendiri, mampu bertahan pada saat mengalami frustasi dan menjaga keselarasan emosi dengan cara pengendalian diri, mengontrol dorongan (impulse), empati, dan keterampilan sosial (Goleman, 1995). Seorang remaja yang memiliki sikap dan perilaku yang positif adalah seorang remaja yang memiliki kemampuan untuk mengendalikan diri dengan baik, mampu memahami perasaan diri sendiri dan orang lain, dan mampu membina hubungan yang baik dengan orang lain, dengan demikian remaja tersebut dapat dikatakan sebagai remaja yang memiliki kecerdasan emosional yang tinggi (Indrayana \& Hendrati, 2013).

Berdasarkan paparan diatas, peneliti tertarik untuk meneliti hubungan antara konformitas dan kecerdasan emosional terhadap agresivitas pada remaja di SMAN 7 Denpasar, selain itu dari beberapa kasus dan hasil penelitian yang telah dipaparkan peneliti diatas memiliki persamaan yaitu tindak kekerasan yang dilakukan oleh remaja secara berkelompok dan persepsi bahwa adanya hubungan antara konformitas dan kecerdasan emosional terhadap agresivitas inilah yang membuat peneliti ingin mengambil judul penelitian ini.

\section{METODE}

\section{Variabel dan Definisi Operasional}

Variabel bebas yang dilibatkan dalam penelitian ini adalah konformitas dan kecerdasan emosional sedangkan variabel tergantung yang di dalam penelitian ini adalah agresivitas. Adapun definisi operasional dari masing-masing variabel adalah sebagi berikut:

1. Agresivitas

Agresivitas adalah kecenderungan menyakiti atau melukai orang lain sebagai pertahanan diri akibat adanya rasa kekecewaan dari dalam diri. Agresivitas diukur dengan skala agresivitas yang disusun berdasarkan aspek-aspek agresivitas yang dikemukakan oleh Buss and Perry yaitu agresi fisik (physical aggression), agresi verbal (verbal aggression), rasa marah (anger), dan permusuhan (hostility). Skor total aitem yang diperoleh menunjukkan seberapa tinggi tingkat agresivitas pada subjek. Semakin tinggi skor total, menunjukkan bahwa semakin tinggi agresivitas pada subjek.

\section{Konformitas}

Konformitas adalah perubahan perilaku sebagai akibat dari tekanan kelompok. Konformitas diukur dengan menggunakan skala konformitas yang disusun berdasarkan tiga aspek oleh Sears yaitu peniruan, penyesuaian, dan kepercayaan. Skor total aitem yang diperoleh menujukkan seberapa tinggi konformitas pada diri subjek. Semakin tinggi skor total, menujukkan semakin tinggi konformitas yang ada pada diri subjek.

\section{Kecerdasan Emosional}

Kecerdasan emosional adalah kemampuan untuk memotivasi diri sendiri dan bertahan ketika individu mengalami suatu keadaan yang membuat frustasi, mengendalikan dorongan hati serta tidak melebih-lebihkan kesenangan yang dirasakan, mengatur suasana hati dan juga menjaga agar beban stres yang ada tidak melumpuhkan kemampuan berpikir, berempati, serta berdoa.

Kecerdasan emosional diukur dengan skala kecerdasan emosional yang disusun berdasarkan lima aspek kecerdasan emosional dari Goleman yaitu mengenali emosi diri, mengelola emosi, memotivasi diri sendiri, mengenali emosi orang lain, dan membina hubungan. Skor total aitem yang diperoleh menujukkan seberapa tinggi kecerdasan emosional yang dimiliki oleh subjek. Semakin tinggi skor total, menujukkan bahwa semakin tinggi kecerdasan emosional.

\section{Responden}

Populasi pada penelitian ini adalah remaja madya di SMAN 7 Denpasar. Krtiteria subjek pada penelitian ini adalah sebagai berikut: 
1. Berusia 15-18 tahun

2. Berjenis kelamin laki-laki dan perempuan

Teknik yang dilakukan dalam menentukan sampel adalah teknik proportionate stratified random sampling yaitu pengambilan anggota sampel dari populasi dilakukan secara merata sesuai dengan tingkatan atau strata yang ada di (Sugiyono, 2012). Jumlah sampel pada penelitian ini adalah 226 orang.

\section{Tempat Penelitian}

Pengambilan sampel dilakukan di Denpasar, pada remaja madya di SMAN 7 Denpasar. Penelitian ini dilaksanakan pada bulan April 2015.

\section{Alat Ukur}

Skala yang digunakan pada kuisioner adalah skala agresivitas yang dimodifikasi oleh peneliti dari Buss dan Perry (dalam Bryant \& Smith 2001), skala kecerdasan emosional yang dimodifikasi oleh peneliti dari Simarmata (2005) dan skala konformitas yang disusun oleh peneliti. Skala agresivitas terdiri dari 20 aitem, skala konformitas terdiri dari 25 aitem dan skala kecerdasan emosional terdiri dari 20 aitem dengan menggunakan model skala likert dengan empat kategori pilihan jawaban. Skala likert ini digunakan karena dengan menggunakan skala ini dapat terlihat berbedaan yang menunjukkan intensitas pada setiap pilihan jawaban. Selain itu kuesioner ini juga terdiri dari aitem favorable dan aitem nonfavorable

Hasil pengujian validitas skala agresivitas didapatkan hasil koefisien korelasi item total bergerak dari 0,284-0,692. Hasil pengujian reliabilitas skala agresivitas pada saat uji coba adalah 0,882 yang menunjukkan bahwa skala ini mampu mencerminkan $88,20 \%$ variasi yang terjadi pada skor murni subjek yang bersangkutan sehingga alat ukur layak digunakan sebagai alat ukur untuk mengukur variabel agresivitas.

Pada hasil pengujian validitas konformitas didapatkan hasil koefisien korelasi item total bergerak dari $0,257-0,712$. Hasil pengujian reliabilitas skala konformitas pada saat uji coba adalah 0,902 yang menunjukkan bahwa skala ini mampu mencerminkan 90,20\% variasi yang terjadi pada skor murni subjek yang bersangkutan sehingga alat ukur layak digunakan sebagai alat ukur untuk mengukur variable konformitas.

Pada hasil pengujian validitas kecerdasan emosional didapatkan hasil koefisien korelasi item total bergerak dari 0,284-0,692. Hasil pengujian reliabilitas skala kecerdasan emosional pada saat uji coba adalah 0,872 yang menunjukkan bahwa skala ini mampu mencerminkan $87,20 \%$ variasi yang terjadi pada skor murni subjek yang bersangkutan sehingga alat ukur layak digunakan sebagai alat ukur untuk mengukur variable kecerdasan emosional.

\section{Teknik Analisis Data}

Teknik analisis data yang digunakan dalam penelitian ini adalah dengan menggunakan metode analisis regresi berganda dan korelasi parsial. Metode analisis regresi berganda digunakan untuk melihat hubungan lebih dari satu variabel bebas dan satu variabel terikat. Metode analisis korelasi parsial digunakan untuk mengukur korelasi antar dua variabel tanpa terkena pengaruh dari variabel lainnya (Santoso, 2005). Analisis regresi berganda dilakukan untuk membuktikan hipotesis mayor dan korelasi parsial dilakukan untuk membuktikan hipotesis minor. Analisis data dilakukan dengan menggunakan bentuan perangkat lunak SPSS versi 17.0. Sebelum melakukan analisis regresi berganda dan korelasi parsial, peneliti melakukan uji normalitas, uji linearitas dan uji multikolinearitas. Pada penelitian ini, uji normalitas dilakukan dengan menggunakan Kolmogorov Smirnov, uji linearitas dilakukan dengan menggunakan Compare Means dan uji multikolinearitas dilakukan dengan melihat besaran variance inflation factor (VIF) dan tolerance dari model regresi.

\section{HASIL PENELITIAN}

\section{Karakteristik Subjek}

Subjek dalam penelitian ini berjumlah 226 orang dengan 95 orang berjenis kelamin laki-laki dan 131 orang berjenis kelamin perempuan. Subjek terdiri dari 113 siswa kelas I dan 113 siswa kelas II orang dengan rentang usia 15sampai 17 tahun.

\section{Deskripsi Data Penelitian}

\begin{tabular}{lcccccccc}
$\begin{array}{l}\text { Tabel 1. } \\
\text { Deskripsi Statistik Data Penelitian }\end{array}$ & & & & \\
\hline Variabel & $\mathbf{N}$ & $\begin{array}{c}\text { Mean } \\
\text { Teoritis }\end{array}$ & $\begin{array}{c}\text { Mean } \\
\text { Empiris }\end{array}$ & $\begin{array}{c}\text { Std } \\
\text { Deviasi } \\
\text { Teoritis }\end{array}$ & $\begin{array}{c}\text { Std } \\
\text { Deviasi } \\
\text { Empiris }\end{array}$ & $\begin{array}{c}\text { Sebaran } \\
\text { Teoritis }\end{array}$ & $\begin{array}{c}\text { Sebaran } \\
\text { Empiris }\end{array}$ & Nilai T \\
\hline Agresivitas & 226 & 50 & 48,47 & 10 & 7,689 & $20-80$ & $34-80$ & $\begin{array}{c}94,773 \\
(\mathrm{p}=0,000)\end{array}$ \\
\hline Konformitas & 226 & 62,5 & 54,03 & 12,5 & 5,837 & $25-100$ & $39-74$ & $\begin{array}{c}139,168 \\
(\mathrm{p}=0,000)\end{array}$ \\
\hline $\begin{array}{c}\text { Kec. } \\
\text { Emosional }\end{array}$ & 226 & 50 & 55,28 & 10 & 6,016 & $20-80$ & $42-76$ & $\begin{array}{c}138,141 \\
(\mathrm{p}=0,000)\end{array}$ \\
\hline
\end{tabular}

Berdasarkan tabel 1 diatas, dapat dilihat bahwa terdapat perbedaan mean teoritis dan mean empiris pada skala agresivitas. Mean teoritis terlihat lebih tinggi daripada mean empirik yaitu sebesar 50 dan memiliki $\mathrm{T}$ sebesar 94,773 $(p=0,000)$. Hal ini menunjukkan bahwa terdapat perbedaan yang signifikan antara mean teoritis dan mean empiris pada skala agresivitas. Dilihat dari distribusi frekuensi terdapat sebanyak 65,5\% skor subjek yang berada diatas mean teoritis.

Pada tabel 1diatas, dapat dilihat bahwa terdapat perbedaan mean teoritis dan mean empiris pada skala konformitas. Mean teoritis lebih tinggi daripada mean empiris

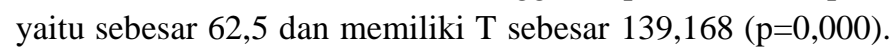
Hal ini menunjukkan bahwa terdapat perbedaan yang signifikan antara mean teoritis dan mean empiris pada skala konformitas. Dilihat dari distribusi frekuensi terdapat 
sebanyak $37,18 \%$ skor subjek yang berada diatas mean teoritis.

Pada tabel 1 diatas terdapat perbedaan mean teoritis dan mean empiris pada skala kecerdasan emosional. Mean teoritis lebih kecil daripada mean empiris yaitu sebesar 50 dan memiliki $\mathrm{T}$ sebesar 138,141 ( $\mathrm{p}=0,000)$. Hal ini menujukkan bahwa terdapat perbedaan yang signifikan antara mean teoritis dengan mean empiris pada skala kecerdasan emosional. Skor subjek memiliki rentang dari 42 sampai 76 dan dilihat dari distribusi frekuensi terdapat sebanyak $96,5 \%$ skor subjek yang berasa diatas mean teoritis. Berikut ini merupakan hasil dari kategorisasi skala kecerdasan emosional.

\section{Uji Asumsi}

Tabel 2.

Hasil Uji Normalitas

\begin{tabular}{ccc}
\hline Vasiabel & Kolmogorof-smirnov & $\begin{array}{c}\text { Asymp. Sig. (2-tailed) } \\
\text { (P) }\end{array}$ \\
\hline Agresivitas & 1,001 & 0,269 \\
\hline Konformitas & 1,121 & 0,162 \\
\hline Kec. Emosional & 0,908 & 0,382 \\
\hline
\end{tabular}

Uji normalitas dilakukan dengan menggunakan teknik Kolmogorof Smirnov pada program spss (Santoso, 2005). Jika hasil p>0.05 maka data dapat dikatakan normal. Berdasarkan tabel 2, diketahui bahwa data dari agresivitas menghasilkan nilai Kolmogorof Smirnov sebesar 1,001 dengan signifikansi 0,269 ( $\mathrm{p}>0,05)$. Hal ini menunjukkan data pada variabel agresivitas memiliki distribusi normal. Data dari konformitas menghasilkan nilai Kolmogorof Smirnov sebesar 1,121 dengan signifikansi 0,162 (p>0,05). Hal ini menunjukkan data pada variabel konformitas memiliki distribusi normal. Data dari kecerdasan emosional menghasilkan nilai Kolmogorof Smirnov sebesar 0,908 dengan signifikansi 0,382 ( $p>0,05)$. Hal ini menunjukkan data pada variabel kecerdasan emosional memiliki distribusi normal.

Tabel 3 .

Hasil Uji Linearitas

\begin{tabular}{ccccc}
\hline Agresivitas*Konformitas & Between & Combined & 2,231 & Signifikansi \\
& Groups & $\begin{array}{c}\text { Linearity } \\
\text { Deviation } \\
\text { Agresivitas*Kec.emosional }\end{array}$ & $\begin{array}{c}38,398 \\
0,840\end{array}$ & 0,000 \\
& from linearity & 0,692 \\
& Groups & Combined & 1,937 & 0,003 \\
& & $\begin{array}{c}\text { Linearity } \\
\text { Deviation } \\
\text { from linearity }\end{array}$ & 3,318 & 0,000 \\
& & 0,939 & 0,560 \\
\hline
\end{tabular}

Hubungan dua variable dapat dikatakan linear jika nilai signifikansi pada linearity lebih kecil dari 0,05. Dari hasil uji linearitas yang ditunjukkan pada tabel 3 menunjukkan hubungan yang linear antara variabel agresivitas dan konformitas dengan nilai signifikansi sebesar 0,000. Variabel agresivitas dan kecerdasan emosional menunjukkan hubungan yang linear dengan nilai signifikansi sebesar 0,000 yang berada dibawah 0,05. Dengan demikian dapat disebutkan terdapat hubungan linear antara agresivitas dengan konformitas dan agresivitas dengan kecerdasan emosional.
Tabel 4 Hasil Uji Multikolinearitas

\begin{tabular}{cccc}
\hline Variabel & Tolerance & $\begin{array}{c}\text { Variance Inflation } \\
\text { Factor (VIF) }\end{array}$ & Keterangan \\
\hline Konformitas & 0,882 & 1,134 & $\begin{array}{c}\text { Tidak ada } \\
\text { multikolinieritas }\end{array}$ \\
\hline $\begin{array}{c}\text { Kecerdasan } \\
\text { Emosional }\end{array}$ & 0,882 & 1,134 & $\begin{array}{c}\text { Tidak ada } \\
\text { multikolinieritas }\end{array}$ \\
\hline
\end{tabular}

Dari hasil uji multikolinearitas pada tabel 4 diatas menunjukkan bahwa nilai koefisien tolerance pada konformitas adalah 0,882 dan koefisien tolerance untuk kecerdasan emosional adalah 0,882. Koefisien VIF untuk konformitas adalah 1,134 dan koefisien VIF untuk kecerdasan emosional adalah 1,134. Koefisien tolerance kedua variabel bebas di atas 0,1 , begitu juga koefisien VIF kedua variabel bebas di bawah 10, maka dapat disimpulkan bahwa model regresi pada penelitian ini tidak memiliki masalah pada multikolinearitas

Berdasarkan hasil dari uji normalitas, uji linearitas, dan uji multikolonieritas dapat terlihat bahwa di persamaan regresi ini memiliki ditribusi data yang normal, bebas dari permasalahan multikolinearitas, normalitas, dan linearitas. Analisis bisa berlanjut ke tahap selanjutnya yaitu analisis regresi berganda dan korelasi parsial.

\section{Uji Hipotesis}

\section{Uji Regresi Berganda}

Berikut ini merupakan hasil uji regresi berganda antara konformitas dan kecerdasan emosional terhadap agresivitas:

Tabel 5.

Hasil Uji Korelasi Regresi Konformitas dan Kecerdasan Emosional Terhadap Agresivitas \begin{tabular}{cccc}
\hline $\mathrm{R}$ & $\mathrm{R}$ Square & Adjusted R Square & Std. Error of the Estimate \\
\hline 0,452 & 0,205 & 0,197 & 6,889
\end{tabular}

Berdasarkan hasil uji regresi pada tabel 5 menunjukkan koefisien $\mathrm{R}$ adalah 0,452 dan koefisien determinasi pada penelitian ini adalah sebesar 0,205 yang berarti sumbangan efektif dari variabel konformitas dan kecerdasan emosional terhadap agresivitas adalah sebesar $20,5 \%$ dan sisanya sebesar $79,5 \%$ dipengaruhi oleh variabel lain yang tidak diteliti oleh peneliti. Hal ini menunjukkan bahwa konformitas dan kecerdasan emosional mampu meramalkan agresivitas sebesar20,5\%.

\begin{tabular}{|c|c|c|c|c|c|}
\hline \multicolumn{6}{|c|}{ Sum of } \\
\hline & Squares & Df & Square & $\mathrm{F}$ & Sig. \\
\hline Regression & 2720,636 & 2 & 1360,318 & 28,667 & 0,000 \\
\hline Residual & 10581,705 & 223 & 47,452 & & \\
\hline Total & 13302,341 & 225 & & & \\
\hline
\end{tabular}

Pada tabel 6, didapat $\mathrm{F}$ hitung adalah 28,667 dengan taraf signifikansi 0,000. Model regresi dapat digunakan untuk memprediksi agresivitas karena signifikansi berada dibawah 0,0, sehingga dapat dijelaskan bahwa konformitas dan kecerdasan emosional memilki hubungan terhadap agresivitas. 
Tabel 7.

Hasil Uji Regresi Berganda Nilai Koefisien Beta dan Nilai T Variabel Konformitas dan Kecerdasan Emosional Terhadap Agresivitas

\begin{tabular}{|c|c|c|c|c|c|}
\hline \multirow[b]{2}{*}{ Model } & \multicolumn{2}{|c|}{ Unstandarized Coefficients } & $\begin{array}{l}\text { Standarized } \\
\text { Coefficient }\end{array}$ & \multirow[b]{2}{*}{$\mathrm{t}$} & \multirow[b]{2}{*}{ Sig. } \\
\hline & $\mathrm{B}$ & Std. Error & Beta & & \\
\hline \multirow{3}{*}{$\begin{array}{l}\text { (Constant) } \\
\text { Konformitas } \\
\text { Kec.Emosional }\end{array}$} & 44,971 & 7,411 & & 6,068 & 0,000 \\
\hline & 0,394 & 0,084 & 0,281 & 4,700 & 0,000 \\
\hline & $-0,322$ & 0,081 & 0,063 & $-3,956$ & 0,000 \\
\hline
\end{tabular}

Dari hasil pada tabel 7, dapat terlihat variabel bebas mana yang lebih berpengaruh terhadap agresivitas. Variabel konformitas memiliki koefisien beta yang tidak terstandarisasi 0,394 dengan nilai t sebesar 4,700 dengan taraf signifikansi $0,000(\mathrm{p}<0,05)$ yang berarti konformitas berpengaruh secara signifikan terhadap agresivitas. Variabel kecerdasan emosional memiliki koefisien beta yang tidak terstandarisasi sebesar -0,322 dengan $t$ hitung sebesar -3,956 dengan taraf signifikansi $0,000(\mathrm{p}<0,05)$ yang berarti kecerdasan emosional berpengaruh secara signifikan terhadap agresivitas.

\section{Uji Korelasi Parsial}

Tabel.8.

Hasil Uji Korelasi Parsial Dengan Mengontrol Variabel Konformitas

\begin{tabular}{llcrr}
\hline Controlvariable & \multicolumn{3}{c}{$\begin{array}{l}\text { Kecerdasan } \\
\text { emosional }\end{array}$} & Agresivitas \\
\hline konformitas & $\begin{array}{l}\text { Kec. } \\
\text { Emosional }\end{array}$ & Correlation & 1,000 & $-0,256$ \\
\cline { 3 - 5 } & & Sig & & 0,000 \\
\cline { 3 - 5 } & Df & 0 & 0,223 \\
\cline { 2 - 5 } & Agresivitas & Correlation & $-0,256$ & 1,000 \\
\cline { 3 - 5 } & & Sig & 0,000 &. \\
\cline { 3 - 5 } & & Df & 0,223 & 0
\end{tabular}

Hasil tabel 24 diatas merupakan korelasi antara kecerdasan emosional dengan agresivitas yang dikontrol oleh variabel konformitas, didapatkan koefisien korelasi antara kecerdasan emosional dengan agresivitas sebesar -0,256 dengan taraf signifikansi sebesar 0,000 ( $\mathrm{p}<0,05)$. Korelasi antara kecerdasan emosional dan agresivitas sebesar -0,256 yang menunjukkan bahwa variabel kecerdasan emosional dan agresivitas memiliki hubungan yang negatif. Hubungan negatif yang dimaksud adalah semakin tinggi kecerdasan emosional, maka tingkat agresivitas akan menurun

Tabel.9.

Hasil Uji Korelasi Parsial Dengan Mengontrol Variabel Kecerdasan Emosional Correlations

\begin{tabular}{|c|c|c|c|c|}
\hline \multicolumn{3}{|c|}{ Control Variables } & \multirow{2}{*}{\begin{tabular}{r|} 
agresivitas \\
1.000
\end{tabular}} & \multirow{2}{*}{$\begin{array}{r}\text { Konformitas } \\
.300\end{array}$} \\
\hline kec.emosional & agresivitas & Correlation & & \\
\hline & & Significance (2-tailed) & & .000 \\
\hline & & $\mathrm{Df}$ & 0 & 223 \\
\hline & konformitas & Correlation & .300 & 1.000 \\
\hline & & Significance (2-tailed) & .000 & \\
\hline & & Df & 223 & 0 \\
\hline
\end{tabular}

Hasil tabel 9 diatas merupakan korelasi antara konformitas dengan agresivitas yang dikontrol oleh variabel kecerdasan emosional. Koefisien korelasi antara konformitas dengan agresivitas sebesar 0,300 dengan taraf signifikansi $0,000(\mathrm{p}<0,05)$, korelasi antara konformitas dengan agresivitas sebesar 0,300 yang menunjukkan bahwa korelasi variabel konformitas dengan agresivitas lemah. Variabel konformitas dan agresivitas memiliki hubungan yang positif. Hubungan positif yang dimaksud adalah semakin tinggi konformitas akan tingkat agresivitas akan semakin tinggi.

Berikut ini peneliti merangkum hasil uji hipotesis mayor dan minor ke dalam tabel10

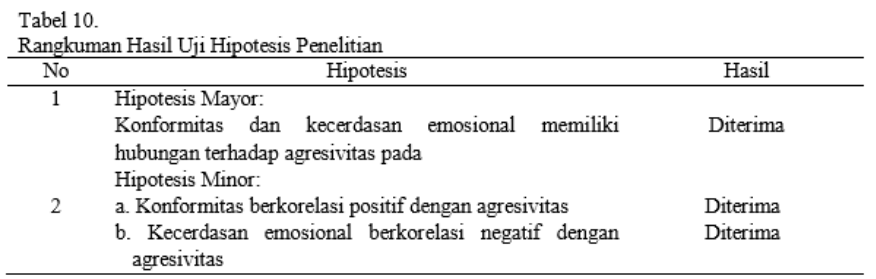

\section{PEMBAHASAN DAN KESIMPULAN}

Berdasarkan hasil analisis regresi berganda yang dilakukan, dapat diketahui bahwa hipotesis mayor terbukti dilihat dari adanya peran yang signifikan dari konformitas dan kecerdasan emosional terhadap agresivitas pada remaja di SMAN 7 Denpasar. Hal ini dapat dilihat dari koefisien $R$ pada hasil uji regresi berganda yaitu sebesar 0,452 dengan $\mathrm{F}$ hitung 28,667 dan taraf signifikansi 0,000 yang menunjukkan bahwa variabel konformitas dan kecerdasan emosional berhubungan terhadap variabel agresivitas. Variabel konformitas dan kecerdasan emosional memiliki sumbangan efektif sebesar $20,5 \%$ terhadap variabel agresivitas, sedangkan 79,5\% merupakan sumbangan dari variabel lain yang tidak diteliti oleh peneliti. Hal ini dapat dilihat dari koefisien determinasi yang didapatkan yaitu sebesar 0,205 dan dapat disimpulkan bahwa konformitas dan kecerdasan emosional menentukan agresivitas remaja sebanyak 20,5\%. Koefisien beta yang terstandarisasi terlihat bahwa variabel bebas yang lebih memengaruhi agresivitas adalah variabel konformitas dengan koefisien beta terstandarisasi sebesar 0,299; nilai t sebesar 4,700 dan taraf signifikansi 0,000.

Masa remaja merupakan masa pencarian identitas dan ingin diakui oleh orang-orang disekitar. Masa remaja juga identik dengan persahabatan dengan teman sebaya yang tidak hanya sekedar pada orientasi aktivitas tetapi sudah lebih luas yaitu mencakup intensitas emosional dan kepercayaan teman sebaya (Prawira,2010). Remaja di dalam tahap perkembangan akan banyak melakukan interaksi dengan individu lain di dalam konteks keluarga, sekolah, dan masyarakat. Interaksi yang dilakukan dapat bersifat negatif ataupun positif. Remaja cenderung akan mengikuti perilaku teman sebaya agar diterima dan diakui oleh teman sebaya atau kelompok, 
perilaku remaja yang mengikuti tingkah laku orang lain karena orang lain menampilkan tindakan tersebut disebut dengan konformitas.

Konformitas dianggap sebagai suatu eksistensi dalam sebuah pergaulan walaupun perilaku yang diciptakan dari sebuah kelompok merupakan perilaku yang negatif dan merujuk ke tindak agresivitas. Hasil analisis korelasi parsial menyatakan bahwa korelasi antara konformitas dan agresivitas memiliki nilai koefisien sebesar 0,386 dengan taraf signifikansi $0,000(\mathrm{p}<0,05)$ dan tidak ada tanda negatif pada hasil koefisien korelasi yang menunjukkan adanya hubungan positif antara variabel konformitas dengan agresivitas.

Hubungan positif memiliki arti bahwa semakin tinggi konformitas maka akan semakin tinggi tingkat agresivitas. Konformitas yang terjadi pada sebuah kelompok karena adanya tekanan untuk diterima oleh kelompok sosial, semakin tinggi keinginan dari individu untuk diterima oleh kelompok sosial makan semakin tinggi pula tingkat konformitas pada individu (Hurlock, 2009). Individu melakukan konformitas tidak hanya pada perilaku positif saja, namun pada perilaku negatif seperti bolos sekolah, meminum minuman keras, dan perilaku yang merujuk ke tindak agresivitas (Sarwono, 2011). Hal tersebut didukung oleh penelitian Megawati (2013) yang mengatakan bahwa semakin tinggi konformitas pada sebuah kelompok atau individu, semakin tinggi kecenderungan untuk melakukan tindak agresivitas.

Berdasarkan hasil penelitian Kurnia, Hardjajani, \& Nugroho (2012) bahwa adanya korelasi negatif signifikan yang rendah antara variabel kecerdasan emosional dengan agresivitas, hal ini menjelaskan bahwa kecerdasan emosional dapat mempengaruhi agresivitas pada remaja. Remaja yang memiliki kecerdasan emosional yang tinggi memiliki kecenderungan agresivitas yang rendah. Remaja yang tidak mampu mengendalikan emosinya sendiri, akan melakukan sesuatu tanpa berpikir panjang terlebih dahulu dan remaja yang mampu mengendalikan emosinya sendiri akan mampu mengarahkan perilakunya sendiri karena kecerdasan emosional merupakan kemampuan individu yang memiliki hubungan dengan kemampuan memahami, mengelola, dan mengendalikan emosi serta mengubah dorongan emosi negatif menjadi emosi positif (Kurnia, Hardjajani, \& Nugroho, 2012).

Agresvitas akan dipengaruhi oleh kecerdasan emosional, karena kecerdasan emosional yang tinggi dapat mengurangi terjadinya agresivitas pada remaja. Hal tersebut didukung oleh penelitian Pratama (2010) yang menyatakan bahwa terdapat hubungan yang signifikan antara kecerdasan emosional dan agresivitas. Kecerdasan emosional yang ditunjukkan oleh remaja yang bersekolah di SMAN 7 Denpasar menunjukkan pengaruh yang signifikan terhadap agresivitas, hal tersebut dapat dilihat dari hasil uji korelasi parsial yang dilakukan pada variabel kecerdasan emosional dan agresivitas sebesar $-0,355(\mathrm{p}<0,05)$ dan memiliki tanda negatif pada koefisien korelasi yang menunjukkan adanya hubungan negatif antara kecerdasan emosional dengan agresivitas pada remaja di SMAN 7 Denpasar. Hubungan negatif yang dimaksud adalah semakin tinggi kecerdasan emosional, maka agresivitas akan semakin rendah. Individu yang memiliki kecerdasan emosi yang tinggi akan mampu mengendalikan emosi dan mengendalikan perasaan agar tidak melewati batas dan terhindar dari tindak agresivitas (Goleman, 1995).

Pada karakteristik subjek berdasarkan umur menunjukkan bahwa sebanyak 49 orang atau sekitar $22 \%$ subjek yang berumur 15 tahun dengan total skor pada skala agresivitas bergerak dari 34 sampaI 64, sebanyak 110 orang atau sekitar $49 \%$ subjek yang berumur 16 tahun dengan total skor pada skala agresivitas bergerak dari 34 sampai 80, sebanyak 66 orang atau sekitar 29\% subjek yang beumur 17 tahun dengan total skor pada skala agresivitas bergerak dari 34 sampai 66, Sebaran skor total menunjukkan bahwa adanya sedikit perbedaan agresivitas berdasarkan umur pada remaja di SMAN 7 Denpasar, dilihat dari hasil skor total pada remaja yang berumur 16 tahun yang mencapai skor tertinggi yaitu 80 .

Remaja yang berusia 15-18 rentan terhadap agresivitas karena sedang mengalami fase peralihan dari masa kanak-kanak ke masa dewasa (Rice, 2001). Remaja yang berusia 15-16 tahun merupakan remaja yang baru memasuki bangku SMA. Remaja tersebut masih menyesuaikan diri dengan lingkungan sekitarnya, memenuhi tuntutan-tuntutan yang berasal dari lingkungannya. Banyaknya tuntutan yang harus dipenuhi membuat remaja menjadi bingung dan emosi remaja akan menjadi fluktuatif. Emosi yang fluktuatif akan membuat remaja mudah untuk melakukan tindakan yang menjurus ke agresivitas (Hurlock, 2013).

Pada karakteristik subjek berdasarkan kelas menunjukkan bahwa sebanyak 113 orang atau sekitar 50\% subjek yang berada di kelas I dengan skor total pada skala agresivitas bergerak dari 34 sampai 80, sebanyak 113 orang atau 50\% subjek yang berada di kelas II dengan skor total pada skala agresivitas bergerak dari 33 sampaI 69, sebaran skor total menunjukkan bahwa adanya sedikit perbedaan agresivitas berdasarkan kelas pada remaja di SMAN 7 Denpasar yang dapat dilihat dari sebaran skor kelas I dan II. Kelas I memiliki skor total tertinggi yaitu 80 dan kelas II memiliki skor total 69, hal ini dapat disimpulkan bahwa ada perbedaan skor agresivitas pada subjek kelas I dan II. Skor kelas I lebih tinggi dibandingkan dengan skor kelas II.

Skor siswa kelas I didapatkan lebih tinggi dibandingkan dengan skor siswa kelas II pada variabel agresivitas karena siswa kelas I merupakan siswa baru yang sedang menyesuaikan diri dengan lingkungan baru, sekolah baru, dan teman baru. Erikson (dalam Myers, 2014) mengatakan bahwa pada masa remaja terdapat tahap 
psikososial yang menekankan pada pencarian identitas diri dan mencari pengakuan dari teman sebaya. Hal lain yang membuat skor siswa kelas I lebih tinggi adalah faktor emosi, remaja yang sedang mengalami fase peralihan akan memiliki emosi yang fluktuatif dan dikelilingi oleh emosi-emosi negatif (Hurlock, 2003).

Hasil dari deskripsi data penelitian, dapat terlihat bahwa pada variabel agresivitas memiliki mean teoritis sebesar 50 dan mean empiris sebesar 48,47 yang menunjukkan bahwa subjek memiliki agresivitas yang rendah (mean teoritis $>$ mean empiris). Masa remaja merupakan masa yang rentan dengan tindak agresivitas terkait dengan emosi yang fluktuatif dan ditambah dengan beberapa faktor yang mempengaruhinya seperti faktor keluarga, faktor teman sebaya, dan faktor lingkungan (Sarwono, 2002). Individu yang memiliki tingkat agresivitas yang rendah akan mudah bergaul dengan teman sebaya dan interaksi dengan keluarga berjalan dengan baik (Gunarsa \& Gunarsa, 2012)

Thalib (2010) mengatakan bahwa emosi yang muncul pada remaja berupa rasa kejengkelan dan emosi marah, remaja yang tidak mampu menyesuaikan diri dengan lingkungan akan cenderung mudah untuk marah dan jengkel. Perasaan marah yang dialami oleh remaja akan biasanya akan dilampiaskan dalam bentuk perilaku yaitu perilaku agresif yang merujuk ke tindak agresivitas.

Hasil dari kategorisasi data agresivitas menunjukkan tidak ada subjek yang memiliki tingkat agresivitas yang sangat rendah, sedangkan terdapat 8 orang atau 3,5\% subjek yang memiliki tingkat agresivitas rendah, sebanyak 106 orang atau sekitar $47 \%$ subjek yang memiliki tingkat agresivitas sedang, terdapat 100 orang atau sekitar 44,2\% subjek yang memiliki tingkat agresivitas tinggi, dan sebanyak 12 orang atau 5,3\% subjek yang memiliki tingkat agresivitas sangat tinggi.

Pada deskripsi data penelitian, ditunjukkan bahwa variabel konformitas memiliki mean teoritis sebesar 62,5 dan mean empiris sebesar 54,03 yang menujukkan bahwa subjek memiliki tingkat konformitas yang rendah (mean teoritis > mean empiris). Remaja yang memiliki tingkat konformitas yang rendah akan memiliki rasa percaya diri yang tinggi dalam melakukan segala sesuatu hal yang sesuai dengan keinginannya tanpa melihat perilaku orang lain (Sears, 1999). Seseorang melakukan konformitas karena adanya rasa takut apabila tidak diterima oleh kelompok, ketakutan dianggap menyimpang, dan menghindari celaan (Yuliana, 2013).

Hasil tingkat konformitas yang rendah dapat dikarenakan oleh beberapa faktor yaitu faktor deindividuasi, kepercayaan diri, komitmen, dan keseragaman kelompok. Deindividuasi terkait dengan individu yang ingin terlihat berbeda dengan individu lainnya, perilaku ini muncul karena SMAN 7 Denpasar merupakan salah satu SMA Negeri unggulan di Denpasar. SMAN 7 Denpasar menjadi salah satu SMA Negeri favorit di Denpasar karena dilihat dari nilai ratarata yang diperoleh sekolah tersebut tinggi dan proses penyeleksian untuk masuk ke SMAN 7 yang tergolong ketat dengan standar yang cukup tinggi. Peneliti mengasumsikan bahwa deindividuasi dapat terjadi karena individu ingin menonjolkan dirinya yang unik dan berbeda dengan lainnya (Prawira, 2014).

Deindividuasi membuat tingkat konformitas remaja menjadi rendah karena remaja memiliki pemikiran-pemikiran kolektif (Li, 2010). Tingginya deindividuasi seseorang berkaitan dengan kecerdasan emosional yang dimilikinya. Individu yang memiliki tingkat kecerdasan emosional yang tinggi tidak akan mudah terbawa arus kelompok karena pemikiran-pemikiran kolektif yang dimilikinya, mampu diperlakukan sebagai seorang individu di tengah-tengah kelompok tanpa harus mencontoh perilaku orang disekitarnya (Lupton, 2004).

Deindividuasi atau keinginan individu untuk terlihat berbeda dengan orang lain berhubungan dengan rasa percaya diri yang dimiliki oleh individu tersebut. Tingkat konformitas itu sendiri akan mengalami penurunan apabila individu mampu meningkatkan kepercayaan diri dan melakukan penilainnya terhadap diri sendiri. Jika hal ini tersebut terajadi, maka kelompok bukan lagi sumber utama sebagai tolak ukur dalam berperilaku dan individu akan mampu melakukan halhal tanpa harus melihat kepada orang lain. Faktor lainnya adalah komitmen, remaja yang memiliki komitmen rendah akan diasumsikan memiliki tingkat konformitas yang rendah, komitmen yang rendah dapat terjadi apabila tidak ada hal-hal yang membuat individu tersebut harus berkomitmen dengan kelompoknya (Taylor, Peplau, \& Sears, 2009). Faktor selanjutnya adalah keseragaman kelompok, penurunan konformitas yang ekstrim diakibatkan oleh ketidakkompakkan yang disebabkan oleh tingkat keyakinan pada kelompok akibat terjadinya perselisihan dan faktor keengganan untuk menonjol (Taylor, Peplau, \& Sears, 2009).

Hasil dari kategorisasi skala konformitas menunjukkan bahwa terdapat 12 orang atau sekitar 25,3\% subjek yang memiliki tingkat konformitas yang sangat rendah, sebanyak 130 orang atau sekitar 57,52\% subjek yang memiliki tingkat konformitas yang rendah, sebanyak 83 orang atau sekitar $36,74 \%$ subjek yang memiliki tingkat konformitas yang sedang, dan sebanyak 1 orang atau sekitar $0,41 \%$ subjek yang memiliki tingkat konformitas yang tinggi.

Berdasarkan hasil deskripsi dari data penelitian, ditunjukkan bahwa variabel kecerdasan emosional memiliki mean teoritis sebesar 50 dan mean empiris sebesar 55,28 yang menunjukkan bahwa subjek penelitian memiliki kecerdasan emosional yang tinggi (mean teoritis < mean empiris). Remaja yang memiliki kecerdasan emosional yang tinggi cenderung mampu untuk mengelola emosi dan mengenali perasaan 
dengan baik dan akan terhindar dari depresi (Goleman, 2005). Apabila individu memiliki kecerdasan yang baik, individu tersebut akan mampu mengelola emosi dengan tepat, mampu memahami perasaan orang lain dan diri sendiri, oleh karena itu individu akan mampu membina hubungan baik dengan orang lain (Ratnasari \& Muttaqiyathun, 2012)

Pada akhirnya, setelah melalui proses uji analisis, penelitian ini telah mampu menjawab pertanyaan dari rumusan masalah dan mampu mencapai tujuan yang telah diuraikan di bab sebelumnya bahwa untuk mengetahui hubungan konformitas dan kecerdasan emosional terhadap agresivitas pada remaja di SMAN 7 Denpasar, mengetahui hubungan antara konformitas dan agresivitas pada remaja di SMAN 7 Denpasar, dan untuk mengetahui hubungan antara kecerdasan emosional dan agresivitas pada remaja madya di SMAN 7 Denpasar.

Berdasarkan penelitian yang telah dilakukan, maka dapat ditarik kesimpulan yaitu variabel konformitas dan kecerdasan emosional memiliki hubungan terhadap agresivitas pada remaja madya di SMAN 7 Denpasar. Konformitas memiliki hubungan yang positif dan searah dengan agresivitas pada remaja madya di SMAN 7 Denpasar yang berarti bahwa semakin tinggi konformitas, maka semakin tinggi agresivitas pada remaja madya di SMAN 7 Denpasar. Variabel kecerdasan emosional memiliki hubungan yang negatif dengan agresivitas pada remaja madya di SMAN 7 Denpasar yang berarti semakin tinggi kecerdasan emosional, maka semakin rendah tingkat agresivitas pada remaja madya di SMAN 7 Denpasar. Kesimpulan berdasarkan kategorisasi adalah tingkat agresivitas pada remaja madya di SMAN 7 Denpasar tergolong sedang yaitu sebanyak 50\% subjek memiliki tingkat agresivitas yang sedang, tingkat konformitas pada remaja madya di SMAN 7 Denpasar tergolong rendah, karena 57,52\% subjek memiliki tingkat konformitas yang rendah, dan kecerdasan emosional pada remaja madya di SMAN 7 Denpasar tergolong sedang, karena 47\% subjek memiliki tingkat konformitas yang sedang.

Berdasarkan kesimpulan diatas, peneliti memberikan saran kepada orang tua yaitu orangtua mampu memahami perubahan-perubahan yang terjadi pada anak karena anak sedang dalam fase perubahan dari anak-anak menuju dewasa, orangtua hendaknya memantau kegiatan dan pergaulan anak untuk agar anak tidak terlibat dalam tindak agresivitas di luar maupun di dalam sekolah. Saran untuk remaja madya yaitu remaja madya mampu mengenali dan memahami perasaan diri sendiri dan orang lain sehingga akan meminimalisir terjadinya tindak agresivitas antar remaja, mampu membedakan perilaku mana yang harus ditiru dan mana yang tidak harus ditiru terkait dengan keinginan untuk diterima oleh kelompok sosial, remaja madya hendaknya memilih kegiatan positif didalam pergaulan dan peneliti berharap siswa-siswi mengkomunikasikan setiap permasalahan kepada guru bimbingan konseling maupun orangtua di rumah.

Di dalam sebuah penelitian pasti terdapat kelebihan dan kekurangan, kekurangan yang terdapat pada penelitian ini adalah limitasi pada subjek dan kurangnya teori agresivitas yang membahas tentang variabel konformitas dan agresivitas. Pada penelitian ini subjek yang digunakan hanya berasal dari SMAN 7 Denpasar dan generalisasi penelitian ini hanya dapat dilakukan di SMAN 7 Denpasar saja, dengan menggunakan subjek yang berasal dari berbagai sekolah, hasil penelitian akan mampu di generalisasikan secara luas.

Saran kepada pihak sekolah adalah diharapkan penelitian ini mampu menguraikan dengan jelas mengenai agresivitas, konformitas, dan kecerdasan emosional pada remaja madya, sehingga pihak sekolah khususnya guru bimbingan konseling mampu menjelaskan lebih dalam lagi kepada siswa-siswa mengenai dampak-dampak negatif dari agresivitas dan konformitas yang berlebihan. Saran untuk peneliti selanjutnya adalah peneliti menggunakan SMA negeri lain sebagai subjek penelitian, tidak hanya 1 SMA aja agar subjek bervariasi, menggunakan remaja awal, remaja akhir, dan dewasa awal sebagai subjek untuk melihat perbedaan agresivitas, melakukan penelitian di luar kota Denpasar terkait dengan karakteristik subjek yang bervariasi karena di setiap wilayah memiliki kebiasaan yang berbeda.

\section{DAFTAR PUSTAKA}

Bryant, F. \& Smith, B. (2001). Refining the architecture of aggression: A measurement model for the Buss-Perry aggression questionnaire. Journal of Research in Personality 35, 138-167. Loyola University Chicago. Doi: 2001-07092-003 diunduh tanggal 3 April 2014.

Buhrmester, D. (1996). Need fullfillment, interpersonal competence, and the developmental contexts of early adolescent friendship. In W. M. Bukowsky, A.F. Newcomb, \& W.W Hartup (Eds), The company they keep: Friendship in childhood and adolescence. New York: Cambridge University Press. www.psynet.apa.org/psycinfo/199807411-007 diunduh tanggal 3 April 2014.

Dewi, T. (2012). Hubungan antara kecerdasan emosional dan agresi pada remaja di Jakarta. Skripsi (tidak dipublikasikan), Fakultas Psikologi, Universitas Bina Nusantara, Jakarta. Doi: 18436/1/1550407085 diunduh pada tanggal 10 Februari 2015.

Goleman, D. (1995). Emotional intelligence. New York: Scientific American.

Goleman, D. (2001). Kecerdasan emosional. Jakarta : PT. Gramedia Pustaka Utama.

Gunarsa \& Gunarsa. (2012). Psikologi untuk muda mudi. Jakarta: Libri.

Hurlock, E. B. (1980). Psikologi Perkembangan Suatu Pendekatan Sepanjang Rentang Kehidupan (5th ed.). Jakarta: Erlangga. 
Indrayana, P. \& Hendrati, F. (2013). Hubungan antara kecerdasan emosional dan konformitas kelompok teman sebaya dengan konsep diri remaja. Jurnal Psikologi Indonesia, 2 (3), 199207. Doi : 2012-2-00057 diunduh tanggal 12 Maret 2015.

Kurnia, R., Hardjajani, T. \& Nugroho, A. (2012). Hubungan antara konsep diri dan kecerdasan emosi dengan agresivitas pada siswa kelas XI man Klaten. Jurnal Ilmiah Berkala Psikologi. 8 (1), 46-62. Doi: 196010151987101 diunduh tanggal 7 April 2015.

Li, B. (2010). The theories of deindividuation. CMC Senior Theses. Paper 12.

http://scholarship.claremont.edu/cmc_theses/12 diunduh tanggal 15 Juni 2015.

Lupton, N. (2006). An exploration of emotional intelligence in virtual teams. Tesis (tidak dipublikasikan), Faculty of Graduate Studies and Research, Carleton University, Canada. ISBN: 978-0-494-18351-9 diunduh tanggal 15 Juni 2015.

Myers, D.G. (2014). Psikologi sosial (edisi ke 10.). Jakarta: Salemba Humanika.

Pratama, A. (2010). Hubungan kecerdasan emosi dengan agresivitas pada remaja awal pendukung persija (the jak mania). Skripsi (tidak dipublikasikan), Fakultas Psikologi, Universitas Negeri Syarif Hidayatullah, Jakarta. Doi: 123456789/2063/1/ diunduh tanggal 25 Juni 2014.

Prawira, P.A. (2014). Psikologi pendidikan dalam perspektif baru. Yogyakarta: AR-Ruzz Media.

Ratnasari, D. \& Muttaqiyathun, A. (2011). Pengaruh kecerdasan emosional terhadap kinerja guru pada SD yang terletak di wilayah Tegaltirto. Jurnal Psikologi Pendidikan, 12 (1), 112. Doi: 19753/1/1660206885 diunduh tanggal 20 Maret 2015.

Rice, P.H. (2001). Human development: A life-span approach (4th ed.). New York: Prentice Hall.

Santoso, S. (2003). Mengatasi berbagai masalah statistika dengan SPSS versi 11.5. Jakarta: PT Elex Media Komputindo.

Sarwono, S.W. (2002). Psikologi sosial: Individu dan teori-teori psikologi sosial. Jakarta: Balai Pustaka

Sarwono, S.W. (2005). Psikologi sosial: Psikologi kelompok dan terapan. Jakarta: Balai Pustaka.

Sears, D.O, Free, \&Peplau, L.A. (2002). Psikologi sosial (edisi ke 12.).Jakarta:Erlangga

Simarmata, N. (2005). Hubungan antara kecerdasan emosional dan kepuasan kerja pada karyawan. Skripsi (tidak dipublikasikan), Fakultas Psikologi, Universitas Sanata Dharma, Yogyakarta.

Sugiyono. (2013). Metode penelitian kombinasi (mixed methods). Bandung: Alfabeta.

Thalib, S.B. (2010). Psikologi pendidikan berbasis analisis empiris aplikatif. Jakarta: Kencana Prenada Media Grup.

Yuliana, E. (2013). Hubungan antara konformitas negatif dengan perilaku agresif siswa kelas VIII SMP Negeri 1 Bancak Kabupaten Semarang tahun pelajaran 2012/2013. Skripsi (tidak dipublikasikan), Fakultas Keguruan dan Ilmu Pendidikan, Universitas Kristen Satya Wacana, Semarang. Doi: 1/132009074 diunduh pada tanggal 3 April 2015.

Yusuf, S. (2011). Psikologi perkembangan anak dan remaja. Bandung: Remaja Rosdakarya.ia Pratama. 